\title{
Minerals content, essential oils composition and physicochemical properties of Citrus jambhiri Lush. (Rough Lemon) from the Sudan
}

\author{
Abdelhafeez M. A. Mohammed ${ }^{1, *}$, Amna M. Ibrahim ${ }^{1}$, Ayat A. Omran ${ }^{1}$, \\ Moawia E. Mohamed ${ }^{2}$, Sumaya E. M. Elsheikh ${ }^{2}$ \\ ${ }^{1}$ Department of Chemistry, Faculty of Education, Alzaiem Alazhari University, PO Box 1432, \\ Khartoum North, 13311, Sudan \\ *Tel: +2499288 09281, *Fax: +2491853480078 \\ ${ }^{2}$ Agricultural Research Corporation, Shambat Agricultural Research Station, PO Box 30, \\ Khartoum North, Sudan \\ *E-mail address: ahafeez61@yahoo.com
}

\begin{abstract}
Minerals content of Citrus jambhiri (rough lemon) fruit was qualitatively and quantitatively analyzed using atomic absorption spectroscopy (AAS) and flame atomic emission spectrometry (FAES). The peel, moisture and ash contents of rough lemon were found to be $18.35 \%, 23.75 \%$ and $2.04 \%$ respectively. Vitamin C (ascorbic acid) of rough lemon juice was found to be $70.0 \mathrm{mg} / 100 \mathrm{~g}$. The chemical composition of essential oil of rough lemon peel was determined. The major compound was found to be limonene ( $84.5 \%$ ) followed by sabinene, $\beta$-myrcene, $\alpha$-terpineol, 1,3 -tetradecadiene and linalool.
\end{abstract}

Keywords: Citrus jambhiri; Rutaceae; Atomic Absorption Spectroscopy(AAS); Flame Atomic Emission Spectroscopy (FAES); metal content; essential oils

\section{INTRODUCTION}

The genus Citrus L., of the family Rutaceae, comprises various species of limes, lemons, oranges, grapefruits and mandarins. Species of the genus Citrus are widely cultivated and they are the most popular fruits in the world [1]. The genus Citrus is believed to be native to tropical and subtropical regions of Asia and Malaysian archipelago [2]. Citrus fruits comprise one of the most important tree crops in the Sudan. Most of the species are cultivated in the Sudan for their fruits such as C. aurantifolia Swingle (lime), C. sinensis L. (sweet orange), C. aurantium L. (sour orange), C. reticulata Blanco (mandarin) and C. paradisi Macf (grape fruit).

The peel of Citrus fruits is a potential source of essential oils [1]. Citrus essential oils have been used as flavoring agents in foods, beverages, and liquors and as aromatic agents in perfumery, soap and other household products. The Citrus fruits possess high amounts of bioactive compounds which can influence human health such as vitamin $\mathrm{C}$ [3], carotenoids, flavonoids, limonoids, essential oils, coumarins, acridone alkaloids, soluble fibres and 
minerals [4]. Sadaf and his co-workers studied the variation in the content and composition of essential oil extracted from peel of $C$. jambhiri. Their results showed that tree to tree variation in fruit peel and peel essential oil at different time intervals [1].

Although the efficiency of medicinal plants for curative purposes is attributed to their organic constitutes like vitamins, essential oils, glycosides, ect...., over dose or prolonged injection of medicinal plants leads to the chronic accumulation of different elements which causes various health problems [5]. The essential metals can produce toxic effects when taken in high concentrations, whereas non-essential metals are toxic even in very low concentration for human health. So, elemental contents of the medicinal plants need to be screened for their quality control. Recently, many studies worldwide reported the importance of elemental constituents of the herbal drug plants which enhanced the awareness about trace elements in these plants.

The researchers are trying to link the contents of the trace elements and the medicinal values of the plants. Though much is known about the functional role of a number of elements, the best foreseeable benefit for human health, by mineral nutrition, lies in obtaining the correct amount of supplementation in the right form at the right time.

The aim of this study is to establish the major $(\mathrm{K}, \mathrm{Na}, \mathrm{Ca}$ and $\mathrm{Mg})$ and trace $(\mathrm{Zn}, \mathrm{Cu}$, $\mathrm{Co}, \mathrm{Ni}, \mathrm{Cd}, \mathrm{Pb}, \mathrm{Mn}, \mathrm{Ag}$ and $\mathrm{Fe}$ ) elemental levels in C. jambhiri and whether the use of this plant is safe for consumers according to the world health standards. Moreover, the chemical composition of essential oil of rough lemon peel, and the physiochemical properties of the fruit were investigated.

\section{EXPERIMENTAL}

\section{1. Materials and Methods}

\section{1. 1. Plant material}

The fresh fruits of C. jambhiri (rough lemon) were collected from the Nursery of Shambat, Agricultural Research Corporation, Khartoum North, Sudan, in July 2012. The identity of the plant was confirmed by Dr. Moawia E. Mohamed and the voucher specimen (CJ 001) has been lodged at Botany Herbarium (BDH), Faculty of Science, University of Khartoum, for verification purposes.

\section{1. 2. Isolation of essential oil}

Isolation of essential oils from fresh peel of C. jambhiri (286.26 g) was carried out by maceration in $\mathrm{n}$-hexane $(3 \times 2 \mathrm{~L})$ for $48 \mathrm{~h}$ at room temperature. The $n$-hexane was removed by using rotator evaporator under reduced pressure. The moisture of the oil was removed by adding anhydrous sodium sulfate.

\section{1. 3. GC-MS analysis of the essential oils}

The peel essential oils of $C$. jambhiri were analyzed using electron impact ionization (EI) GC-17A Shimadzu gas chromatograph (GCMS-QP2010Plus).

\section{1. 4. Determination of metal concentration}

The determination of metal was achieved by using Flame Photometry 410, Sherwood Scientific Ltd, United Kingdom and Varian Spectra AA 220FS Atomic Absorption Spectrometer. 


\section{1. 5. Identification of the compounds}

Compounds were identified by using the library databases of NIST147.LIB, NIST27.LIB and WILEY7.LIB.

\section{1. 6. Physiochemical properties of rough lemon}

$45.8 \mathrm{~g}$ of the fruit were taken in a crucible and the moisture content was determined by weight loss of the sample on drying at $105{ }^{\circ} \mathrm{C}$ for $3 \mathrm{~h}$ using the standard method [6]. Then, the dry material was ashed in the muffle furnace at $550{ }^{\circ} \mathrm{C}$ for $3 \mathrm{~h}$ until constant weight obtained and the ash content was calculated.

The ascorbic acid content of the fruit of rough lemon was estimated using 2,6dichlorophenolindophenol (DCPIP) method [7].

For estimation of elements, the ash was converted to chloride by dissolving in $10 \%$ $\mathrm{HCl}$ and evaporated to dryness on water bath. The material was filtered through Whatmann filter paper. Then, the filtrate was tested to determine concentration of metals by either flame atomic emission spectroscopy $(\mathrm{Na}, \mathrm{K}$, and $\mathrm{Ca}$ ) or atomic absorption spectroscopy $(\mathrm{Zn}, \mathrm{Cu}$, $\mathrm{Co}, \mathrm{Ni}, \mathrm{Cd}, \mathrm{Pb}, \mathrm{Mn}, \mathrm{Mg}, \mathrm{Ag}$ and $\mathrm{Fe}$ ).

\section{RESULTS AND DISCUSSION}

The moisture content of the rough lemon fruit was found to be $23.75 \%$. The ash content was determined as $2.04 \%$ compared to the reported results, ranging between 1.7 $3.5 \%$ for different species of Citrus [3]. The ascorbic acid content was found to $70.0 \mathrm{mg} / 100$ $\mathrm{g}$ which is in higher level than those reported for different citrus fruits [3, 8].

The elemental content of $C$. jambhiri fruit was presented in Table 2. The mineral content showed that potassium (K) was the most abundant element present as $1440 \mathrm{ppm}$ which, is in a good agreement with the reported result [9]. Potassium is an important element because of its diuretic nature. This is followed by calcium $(\mathrm{Ca})$ at $1030 \mathrm{ppm}$. High concentration of $\mathrm{Ca}$ is very important because of its role in bones, teeth, muscles and heart functions [10].

Concentration of sodium is $11.48 \mathrm{ppm}$ which is in good agreement with another study done in Bangladesh [8]. Fruits are generally low in natural sodium. Sodium (Na) plays an important role in the transport of metabolites. High sodium intake has been proved increase high blood pressure [8]. The ratio of $\mathrm{K} / \mathrm{Na}$ in any food is an important factor in prevention of hypertension arteriosclerosis, with $\mathrm{K}$ depresses and $\mathrm{Na}$ enhances blood pressure.

The magnesium $(\mathrm{Mg})$ content of the investigated species was found to be $20.8 \mathrm{ppm}$. In humans, $\mathrm{Mg}$ is required in the plasma and extracellular fluid, where it helps in maintaining osmotic equilibrium. It is required in many enzyme-catalyzed reactions, especially those in which nucleotide participate where the reactive species is the magnesium salt, e.g. MgATP. The lack of $\mathrm{Mg}$ is associated with abnormal irritability of muscle and convulsions while excess $\mathrm{Mg}$ causes depression of the central nervous system.

The concentration of iron (Fe) in this plant was found to be $4.49 \mathrm{ppm}$. The permissible limit set by FAO/WHO in edible plants was $20 \mathrm{ppm}$ [11]. Fe is necessary for the formation of haemoglobin and also plays an important role in oxygen and electron transfer in human body [12] and normal functioning of the central nervous system and in the oxidation of carbohydrates, proteins and fats [13]. The observation of anaemia in Fe deficiency may 
probably be related to its role in facilitating iron absorption and in the incorporation of iron into haemoglobin [11].

According to FAO/WHO [11], the permissible limit of $\mathrm{Cu}$ in edible plants is up to 3.0 $\mathrm{ppm}$. In this study, the concentration of $\mathrm{Cu}$ was found to be $0.24 \mathrm{ppm}$.

Nickel is essential for growth of the plant but in the current study it was found to be in negligible amount $(0.07 \mathrm{ppm})$. Fortunately the concentrations of cadmium and lead were not detected since they are non-essential for human body.

$\mathrm{Pb}$ and $\mathrm{Cd}$ cause both acute and chronic poisoning, and also pose adverse effects on kidney, liver, vascular and immune systems [14]. Fortunately, results of the current study showed that the level of $\mathrm{Pb}$ and $\mathrm{Cd}$ was not detected.

The positive impact of zinc supplementation on the growth of some stunted children, and on the prevalence of selected childhood diseases such as diarrhoea, suggests that zinc deficiency is likely to be a significant public health problem, especially in developing countries $[15,16]$. According to FAO's food balance data, it has been calculated that about $20 \%$ of the world's population could be at risk of zinc deficiency [11].

These medicinal plant species have economic and environmental uses depending on their natural characteristics. Some are consumed in human diet while other species have medicinal value and still other species are good resource of minerals and vitamins [17]. The mineral and heavy metal concentration reported herein might not be on par with some of the earlier reports on medicinal plants. The differences observed might be due to different growth conditions, genetic factors, geographical variations in the level of soil fertility, efficiency of mineral uptake, and the analytical procedure employed [18].

The data obtained in the present work will be useful in evaluation of nutritional value of this species as edible plant.

The chemical analysis of essential oil extracted from peel of $C$. jambhiri showed that limonene $(84.5 \%)$ was the most abundant compound followed by sabinene, $\beta$-myrcene, $\alpha$ terpineol, 1,3-tetradecadiene and linalool. These results were in a good agreement with the reported ones [1].

Table 1. Peel, moisture, ash and Vitamin $C$ contents of $C$. jambhiri fruit $(\mathrm{n}=3)$.

\begin{tabular}{ccc}
\hline Parameter & Result & Unit \\
\hline Peel & 18.35 & $\%$ \\
\hline Moisture & 23.75 & $\%$ \\
\hline Ash & 2.04 & $\%$ \\
\hline Vitamin C & 70.0 & $\mathrm{mg} / 100 \mathrm{~g}$ \\
\hline
\end{tabular}


Table 2. Concentrations of metal ion (ppm) in the C. jambhiri fruit $(\mathrm{n}=3)$.

\begin{tabular}{cc}
\hline Metal ion & Concentration \\
\hline $\mathrm{K}^{+}$ & 1440 \\
\hline $\mathrm{Ca}^{2+}$ & 1030 \\
\hline $\mathrm{Na}^{+}$ & 11.48 \\
\hline $\mathrm{Mg}^{2+}$ & 20.80 \\
\hline $\mathrm{Fe}^{2+}$ & 4.49 \\
\hline $\mathrm{Zn}^{2+}$ & 1.14 \\
\hline $\mathrm{Mn}^{2+}$ & 0.80 \\
\hline
\end{tabular}

\begin{tabular}{cc}
\hline Metal ion & Concentration \\
\hline $\mathrm{Cu}^{2+}$ & 0.24 \\
\hline $\mathrm{Ni}^{2+}$ & 0.07 \\
\hline $\mathrm{Co}^{2+}$ & 0.011 \\
\hline $\mathrm{Ag}^{+}$ & 0.003 \\
\hline $\mathrm{Cd}^{2+}$ & $\mathrm{ND}$ \\
\hline $\mathrm{Pb}^{2+}$ & $\mathrm{ND}$ \\
\hline
\end{tabular}

\section{CONCLUSION}

The study revealed that investigated edible plants are good source of $\mathrm{Na}, \mathrm{K}, \mathrm{Ca}, \mathrm{Mg}$ and Fe. The information obtained provides an idea about the nutritional values of the rough lemon fruit. The mineral and heavy metal concentration reported herein might not be on par with some of the earlier reports on the same plants. The differences observed might be due to different growth conditions, genetic factors, geographical variations in the level of soil fertility, efficiency of mineral uptake, and the analytical procedure employed [18].

\section{ACKNOWLEDGMENTS}

Authors are gratefully acknowledged Mr. Omer E. Elbadawi at Department of Chemistry, Faculty of Science, University of Khartoum, the Sudan and the Staff of the Chemical Laboratory at the Geological Research Authority of the Sudan, for their valuable technical help.

\section{References}

[1] Sadaf S., Bhatti H. N., Iqbal Z., Shahid M., J. Chem. Soc. Pak. 3 (2009) 838-843.

[2] Singh G., Singh O., Nat. Prod. Radiance (2002) 8-21.

[3] Ali J., Abid H., Hussain A., J. Chem. Soc. Pak. 32 (2010) 83-86.

[4] Hamdan D., El-Readi M. Z., Tahrani A., Herrmann F., Kaufmann D., Farrag N., El-Shazly A., Wink M., Food Chem. 127 (2011) 394-403. 
[5] Jabeen S., Shah M. T., Khan S., Hayat M. Q., Pakistan. J. Med. Plants Res. 4 (2010) 559-566.

[6] A. O. A. C. Association of Official Analytical Chemists, $15^{\text {th }}$ ed., Washington, USA 1990.

[7] Okeri H. A., Alonge P. O., Pak. J. Pharm. Sci. 19 (2006) 39-44.

[8] Paul D. K., Shaha R. K., Pak. J. Biol. Sci. 7 (2004) 283-242.

[9] Nikdel S., Barros S. M., Proc. Fla State Hort. Soc. 97 (1984) 79-81.

[10] Brody T., Nutritional Biochemistry, $2^{\text {nd }}$ ed., Academic Press. San Diego 1994, USA.

[11] FAO/WHO Contaminants. In: Codex Alimentarius (1st ed, XVII), (1984) FAO/WHO, Codex Alimentarius Commission: Rome, Italy.

[12] Mahapatra A. K., Mishra S., Basak U. C., Panda P. C., Adv. J. Food. Sci. Technol. 4 (2012) 15-21.

[13] Abbasi A. M., Khan M. A., Ahmad M., Zafar M., Khan H. Muhammad N., Sultana S., Afri. J. Biotechnol. 9 (2009) 1643-1650.

[14] Sheded G. M., Pulford I. D., Hamed I. A., J. Arid Environ. 66 (2009) 210-217.

[15] Osendarp S. J., West C. E., Black R. E., J. Nut. 133 (2003) 817-827.

[16] Sian L., Krebs N. F., Westcott J. E., Amer. J. Clin. Nut. 75 (2002) 99-103.

[17] Vasu K., Jakku V. G., Suryam A., Charya S. M., Afri. J. Microbiol. Res. 3 (2009) 418-421.

[18] Ozcan M., Akgul A., Nahrun (Food) 42 (1998) 102-105. 